\title{
Effect of Turkesterone on the Pancreas Histology and Function in Diabetic Rats
}

\section{IJCRR}

Section: Healthcare

Sci. Journal Impact

Factor: 6.1 (2018)

ICV: 90.90 (2018)

(c) (i) (8)

Copyright@IJCRR

\section{Kuchkarova LS', Rokhimova SO², Syrov VN³}

'Department of Human and Animal Physiology, Biology faculty, National University of Uzbekistan, Tashkent, Uzbekistan; ${ }^{2}$ Department of Natural science, Urgench branch of Tashkent Medical Academy, Urgench, Uzbekistan; 3 Institute of the Plant Chemistry of the Academy of Sciences of the Republic of Uzbekistan, Tashkent, Uzbekistan.

\section{ABSTRACT}

Introduction: The wide-ranging positive effects of phytoecdisteroids suggest use them as drugs for the treatment of diabetes and related diseases. Among phytoecdysteroids, a well-expressed hypoglycemic effect is known for turke sterone.

Objective: We aimed to determine the effect of turke sterone on the endocrine and exocrine parameters of the pancreas in alloxan-induced diabetic rats.

Material and Methods: White outbred rats were divided into 4 groups to receive saline or a single dose of alloxan (170 mg/kg, intraperitoneal) and/or turkesterone $(10 \mathrm{mg} / \mathrm{kg} / 24 \mathrm{~h})$ and glibenclamide $(5 \mathrm{mg} / \mathrm{kg} / 24 \mathrm{~h})$ for 10 days. For histological analysis the tail portion of the pancreas was kept in formalin for 3 days, dried in ethanol, parafinized and then stained with hematoxylin-eosin. The glucose, insulin, C-peptide and total protein level in serum, as well as a-amylase activity in serum and pancreas homogenate, were identified by using special kits (Human. Germany).

Results: Diabetes caused complete destruction of the islet apparatus and partial destruction of the pancreatic acini tissue. Treatment with turkesterone of alloxan-induced diabetic rats resulted in restoration of the histostructure of endo- and exocrine pancreas, increase of serum glucose as well as decrease insulin, C-peptide, and total protein level. In addition, turkesterone treatment of alloxan-induced diabetic rats led to an approximation of $\alpha$-amylase activity of pancreas and serum to control value.

Conclusion: This study has shown that turkesterone led to improving the exocrine and endocrine function in alloxan-indused diabetic rats. Hence, it can be recommended for further testing as an anti-pancreatic and anti-diabetic drug in humans.

Key Words: Pancreatic hystostructure, Insulin, Glucose, C-peptide, a-amylase activity

\section{INTRODUCTION}

It is known diabetes can lead to potential complications such as encephalopathy, heart disease, hypertension, tachycardia, kidney damage, stroke, nerve damage, visual impairment, seizures, and other pathologies. ${ }^{1,2}$ So, there is a growing need for multifunctional drugs to treat diabetes and improve its adverse metabolic effects. In recent years, special attention has been given to the treatment with phytoecdysteroids, as these substances have shown to have a wide range of positive effects on different metabolic pathways. Phytoecdisteroids are involved in the regulation of carbohydrates ${ }^{3}$ and protein metabolism. ${ }^{4,5}$ It has been found their antioxidant ${ }^{6,7}$, anti-inflammatory $^{8}$, antiparasitic ${ }^{8}$, immunomodulatory ${ }^{10}$, anabolic ${ }^{4}$ and cholesterol-lowering ${ }^{7}$ properties. Another im- portant property of phytochysteroids is a reduction in blood glucose level. The blood glucose level had been halved, when alloxan-induced diabetic rats were given complex of phytoecdisteroids isolated from Ajuga iva. ${ }^{711}$ The hypoglycemic property was demonstrated in ecdysone, 2-dexoxyecdysone isolated from the Silenepraemixta as well as in 2-deoxyecdisterone and integristeron isolated from Rhaponticum carthamoides. ${ }^{3}$ Ecdysterone, 22-acetylceiasterone and turkesterone isolated from Ajugaturkestanica also decrease glucose level in intact rats. ${ }^{3}$

The most expressed hypoglycemic effect among the mentioned above phytoecdisteroids has been found for turkesterone. Its glucose-lowering effect has been well expressed in intact and in adrenaline-, stress- and alloxan-induced hyperglycemia ${ }^{3}$.In addition to its hypoglycemic property,

\section{Corresponding Author:}

Lubov Salijanovna Kuchkarova, Department of Human and Animal Physiology, Faculty of Biology, National University of Uzbekistan, Tashkent 100174; Phone: 998998748787; Email: Lyubakuchkarova@yahoo.com

ISSN: 2231-2196 (Print)

Received: 20.07 .2020
ISSN: $0975-5241$ (Online)

Revised: 09.09 .2020
Accepted: 12.10 .2020
Published: 12.11 .2020 
turkesterone activates protein synthesis in skeleton muscles, kidneys, and liver. ${ }^{4}$ However, there is no information on the effect of turkesterone on the pancreas function in diabetes mellitus.

The study aimed to determine the effect of turkesterone on the endocrine and exocrine parameters of the pancreas in alloxan-induced diabetic rats.

\section{MATERIALS AND METHODS}

\section{Animals and experimental design}

Outbred male rats with a weight of $200.0 \pm 20.0 \mathrm{~g}$ were used in the experiments. Rats were kept in plastic cages of $50 \times 30 \times 28 \mathrm{~cm}^{3}$ in size 4 animals each under natural light and humidity and room temperature. Rats were fed a vivarium diet with unlimited access to water and food. Water and food were changed daily at the same time between 9.00 and 10.00 p.m.

Rats were divided into 4 groups (one control and three experimental). Before modelling alloxan-induced diabetes experimental groups of animals have fasted for two days with unlimited access to water. All experimental group rats were intraperitoneally injected with alloxan monohydrate (DIAEM, OOO, Moscow) solution (170 mg/kg). After alloxan injection, only rats with a serum glucose level of more than $250 \mathrm{mg} \%$ were obtained for further experiments. Then the first, second and third experimental groups were intraperitoneally injected with saline, turkesterone $(10 \mathrm{mg} / \mathrm{kg} / 24 \mathrm{~h})$ and glibenclamide $(5 \mathrm{mg} / \mathrm{kg} / 24 \mathrm{~h}$ ) (Berlin-Chemie, Germany) respectively for 10 days. Turkesteron (99,5\% pure) was isolated from Ajugaturkestanica in the Institute of the Plant Chemistry of the Academy of Sciences of the Republic of Uzbekistan.

Control group animals were given the equivalent volume of saline at the same time and by the same manner. The day when the alloxan-induced diabetic rats began to receive corrective drugs was accepted as the $0^{\text {th }}$ day of observation. Biochemical parameters were determined on the $10^{\text {th }}$ days of observation. For analysis animals were decapitated at 8-10 a.m. Animal procedures were performed according to the Helsinki Declaration of the World Medical Association 2010.

\section{Preparation of histological and enzymatic ac- tive samples}

After decapitation, the pancreas was removed from the abdomen, cleaned from the fat tissue and weighed. Pancreas tail section was cut and stored for $72 \mathrm{~h}$ in $10 \%$ formalin solution for fixation. Then, the pancreatic section was washed in running water and successively subjected to increased alcohol solutions for dehydration. The preparation was freeze-dried, followed by embedding in paraffin. From each paraffin block, 5-8 $\mu \mathrm{m}$ cross-sections were prepared and stained in hematoxylin-eosin. The preparations were photographed using digital microscopy of the Leake Company (DN-300M). The rest portion of the pancreas was poured with Ringer's solution ( $\mathrm{pH} 7.4)$ in 1:9 ratio and homogenized with Teflon pestle at a speed of $400 \mathrm{rpm}$ in a minute. The obtained pancreatic homogenate was centrifuged at $1500 \mathrm{~g}$ for 15 min. The supernatant was used to determine the activity of $\alpha$-amylase (EC 3.2.1.1). All processes were performed in cold conditions.

\section{Biochemical analysis}

Blood was obtained during rat decapitation into heparintreated tubes. Blood samples were settled for 30 minutes in a cool place and then centrifuged at $1500 \mathrm{~g}$ for 15 minutes. Serum insulin and C-peptide levels were identified with using analyzer Cobas e 411 in the Biochemistry laboratory of the Republican Specialized Scientific-Practical Medical Center of Endocrinology. The blood glucose and total protein level, as well as the activity of $\alpha$-amylase in the serum and pancreas supernatant, was determined using special reagent sets (Human, Germany).

\section{Statistical Analysis}

Statistical analyses were conducted using Student t-test. The arithmetic mean $(\mathrm{M})$, standard error $(\mathrm{m})$, $\mathrm{t}$ coefficient, and statistical significance value $(\mathrm{P})$ were determined. If the $\mathrm{P}$ value was less than 0.05 , the difference between control and experimental animal groups was considered statistically significant.

\section{RESULTS}

\section{Pancreas histological structure}

In the control group animals, the pancreatic acinar cells were almost the same size and shape and located linearly. The round shape of endocrine island with numerous cells was occupied a large space. In alloxan-induced diabetic rats exocrine cells vacuolization, enlarging of blood vessels and overgrowth of connective tissue were registered. The endocrine cells were disorganized and some of them were necrotic. However, turkesterone administration notably attenuated the atrophic changes of acinar cells and distraction of endocrine islets. As circulating tissue in the pancreas was improved the endocrine island and acini recovered their morphological state. Administration of glibenclamide to alloxan-induced diabetic rats also resulted in regeneration of the endocrine island and acinar cells (Figure 1). 


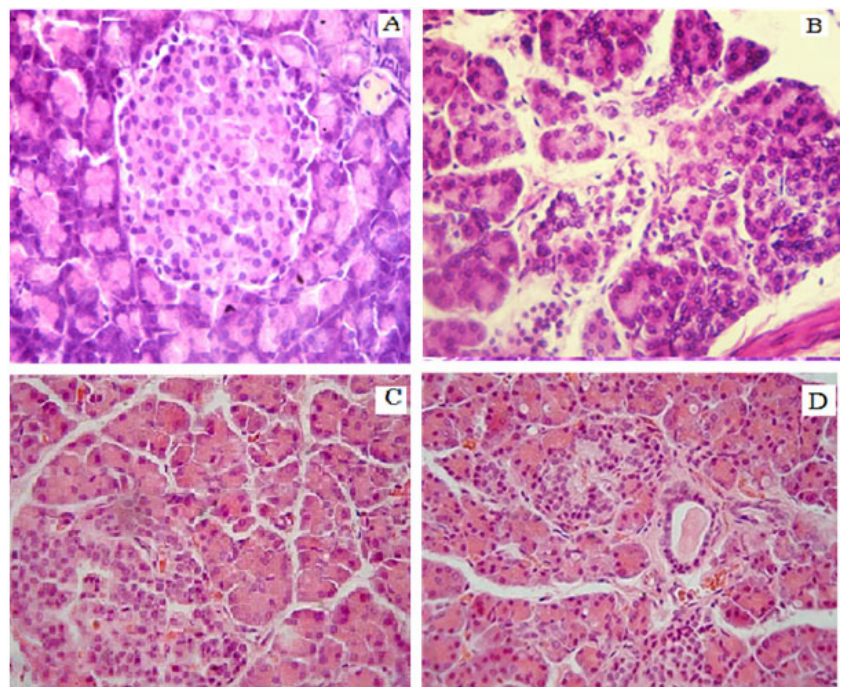

Figure 1: Histological structure of rat pancreas $(H$ and $E$, x400): A. rats treated with saline, B. alloxan-induced diabetic rats, C. alloxan-induced diabetic rats treated with turkesterone, D. alloxan-induced diabetic rats treated with glibenclamide.

\section{Blood glucose, insulin, C-peptide and total pro- tein level}

Serum glucose level was increased by 3.0 times in alloxaninduced diabetic rats. After daily treatment of alloxan-induced diabetic rats with turkesterone the serum glucose level reached the control level. Treatment with glibenclamide of diabetic rats also resulted in the decrease of glucose level, however, it was statistically higher than the control value.

The insulin level was reduced by almost half in alloxan-induced diabetic rats. Treatment of alloxan-induced diabetic rats with both corrective drugs increased of serum insulin level bur it did not reach the control value.

A sharp decrease in C-peptide level was observed in alloxaninduced diabetic rats. Treatment of alloxan-induced diabetic rats with turkesterone and/or glibenclamide during 10 days led to partial recovery of serum C-peptide level. Serum total protein level was also decreased in alloxan-induced diabetic rats. When diabetic rats were injected with turkesterone and/ or glibenclamide, serum protein level was restored to control value (Table 1).

Table 1: Effect of turkesterone on the blood glucose, insulin, C-peptide, and total protein level in the alloxaninduced diabetic rat (Mean $\pm S E M ; n=6)$

\begin{tabular}{|c|c|c|c|c|c|c|}
\hline \multirow{2}{*}{$\begin{array}{l}\text { Animal } \\
\text { groups* }\end{array}$} & \multicolumn{3}{|c|}{ Glucose (Mmol/1) } & \multicolumn{3}{|c|}{ Insulin $(\mu \mathrm{E} / \mathbf{l})$} \\
\hline & Mean \pm SEM & $\%$ & $\mathbf{P}$ & Mean \pm SEM & $\%$ & $\mathbf{P}$ \\
\hline $\mathrm{C}$ & $5.35 \pm 0.38$ & 100.00 & - & $3.16 \pm 0.19$ & 100.00 & - \\
\hline $\mathrm{AD}$ & $15.83 \pm 0.86$ & 295.88 & $<0.001$ & $1.98 \pm 0.10$ & 62.66 & $<0.001$ \\
\hline $\mathrm{AD}+\mathrm{T}$ & $6.52 \pm 0.45$ & 121.86 & $>0.1$ & $2.35 \pm 0.25$ & $74 \cdot 37$ & $<0.02$ \\
\hline \multirow[t]{2}{*}{$\mathrm{AD}+\mathrm{G}$} & $6.86 \pm 0.58$ & 128.22 & $<0.05$ & $2.22 \pm 0.14$ & 70.25 & $<0.002$ \\
\hline & \multicolumn{3}{|c|}{ C- peptide (ng/ml) } & \multicolumn{3}{|c|}{ Total protein $(\mathrm{g} / \mathrm{l})$} \\
\hline C & $0.72 \pm 0.02$ & 100.00 & - & $74.40 \pm 14.7$ & 100.00 & - \\
\hline $\mathrm{AD}$ & $0.14 \pm 0.03$ & 19.44 & $<0.001$ & $52.01 \pm 3.38$ & 69.90 & $<0.02$ \\
\hline $\mathrm{AD}+\mathrm{T}$ & $0.48 \pm 0.03$ & 66.66 & $<0.001$ & $78.21 \pm 5.17$ & 105.12 & $>0.5$ \\
\hline $\mathrm{AD}+\mathrm{G}$ & $0.45 \pm 0.02$ & 62.50 & $<0.001$ & $62.65 \pm 4.51$ & 84.21 & $>0.2$ \\
\hline
\end{tabular}

${ }^{*}$ Group C - rats treated with saline (control), group AD - alloxan-induced diabetic rats, group AD+T alloxan-induced diabetic rats treated with turkesterone, group $\mathrm{AD}+\mathrm{G}$ - alloxan-induced diabetic rats treated with glibenclamide.

\section{a-Amylase activity in pancreas and serum}

In alloxan-induced diabetic rats, pancreas tissue $\alpha$-amylase activity was significantly increased compared with the non-diabetic rat. The treatment of alloxan-induced diabetic rats with turkesterone resulted in a noticeable decrease in enzyme activity. Administration of glibenclamide also approximated the pancreatic enzyme activity to control level in alloxan-induced diabetic rats. Increase of serum $\alpha$-amylase activity was clearly expressed in alloxaninduced diabetic rats compared with control. Treatment of alloxan-induced diabetic rats with turkestone or/and glibenclamide led to the normalization of serum enzyme activity (Table 2).

Table 2: Effect of turkesterone on the $\alpha$-amylase activity in pancreas and serum in alloxan-induced diabetic rats $($ Mean \pm SEM; $\mathbf{n}=6$ )

\begin{tabular}{|c|c|c|c|c|c|c|}
\hline \multirow{2}{*}{$\begin{array}{l}\text { Animal } \\
\text { groups }\end{array}$} & Mean \pm SEM & $\%$ & $\mathbf{P}$ & Mean \pm SEM & $\%$ & $\mathbf{P}$ \\
\hline & \multicolumn{3}{|c|}{ Pancreas (U/g tissue) } & \multicolumn{3}{|c|}{ Serum $(\mathrm{U} / \mathbf{I})$} \\
\hline $\mathrm{C}$ & $36.26 \pm 1.42$ & 100.00 & - & $40.61 \pm 2.32$ & 100.00 & - \\
\hline $\mathrm{AD}$ & $46.29 \pm 2.20$ & 127.66 & $<0.002$ & $62.42 \pm 2.08$ & 143.86 & $<0.01$ \\
\hline $\mathrm{AD}+\mathrm{T}$ & $33.58 \pm 2.31$ & 92.61 & $>0.25$ & $42.81 \pm 1.81$ & 105.42 & $>0.5$ \\
\hline $\mathrm{AD}+\mathrm{G}$ & $42.49 \pm 2.07$ & 120.54 & $<0.02$ & $48.95 \pm 2.81$ & 120.54 & $<0.05$ \\
\hline
\end{tabular}

${ }^{*}$ Group C - rats treated with saline (control), group AD - alloxan-induced diabetic rats, group AD+T - alloxan-induced diabetic rats treated with turkesterone, group $\mathrm{AD}+\mathrm{G}$ - alloxan-induced diabetic rats treated with glibenclamide. 


\section{DISCUSSION}

It is well known that the decrease of insulin and C-peptide levels and the increase of glucose level in serum is the most important diagnostic indicators of diabetes. Such changes take place in patients with type I diabetes and experimental diabetes in animals. ${ }^{712}$ Changes of serum parameters accompanied by shifts in the pancreas histostructure. ${ }^{7}$

The observed overgrowth of connective tissue, enlarging of blood vessel volume, swelling of cell and inflammation in pancreas tissue in alloxan-induced diabetic rats can be a consequence of lipid peroxide oxidation caused by increased glucose level. Diabetes depended increase concentration of serum glucose leads to an increase in oxygen-active forms and degradation of lipids, proteins and nucleic acids in cells and organelles. ${ }^{13}$ The revealed effect of turkesterone in alloxan-induced diabetic rats probably was due to the antiinflammatory and antioxidant properties of phytoecdysteroids. $^{6-8}$

It was shown after treatment of alloxan- or streptozotocininduced diabetic rats with complex phytoecdisteroids isolated from Ajuga iva the serum glucose and cholesterol levels were reduced, and antioxidant enzyme activity such as catalase, superoxidismutase, glutathioneperoxidase was increased dramatically $y^{7,11}$. Increased activity of antioxidant enzymes under the influence of phytoecdisteroids causes a reduction in lipid peroxide oxidation. It is one of the most important factors in the regulation of insulin secretion and serum glucose level. $7,11,14$

Detected in alloxan-induced diabetic rats increasing of the serum $\alpha$-amylase activity is one of the typical signs of pancreatitis. Increasing the level of pancreas enzymes, including $\alpha$-amylase, is the main cause of auto-digestion of the gland in pancreatitis. ${ }^{15}$ So, autophagy may also play a role in the destruction of pancreatic tissue in alloxan-induced diabetic rats.

The existence of a link between the endocrine and exocrine cell pathologies in the pancreas has been also observed by other authors. ${ }^{16,17}$ Decreased of pancreatic $\alpha$-amylase releasing in the small intestine, in alloxan-induced diabetic rabbits. ${ }^{18}$ This data is associated with our results because in pancreatitis, the releasing of pancreatic enzymes into the intestinal cavity is decreased. Alloxan-induced diabetic rabbits did not recover $\alpha$-amylase releasing from pancreas cavity in the intestine even after their treatment with insulin. ${ }^{18}$ Thus, other non-insulin-dependent changes also occur in the pancreas in alloxan-induced diabetes.

Obtained data show the administration of turkesterone to alloxan-induced diabetic rats cause recovering both endocrine and exocrine function of pancreas. Exocrine pancreas recovery was expressed in the normalization ofacinihistostructure and $\alpha$-amylase activity level in glandular tissue and serum.
Wang et al. noted the antidiabetic properties of complex phytoecdisteroids isolated from Ajuga iva plant in 28 days after daily treatment of alloxan-induce ddiabetic rats 7 . Obtained data show diabetes correcting effect of turkesterone appears in 10 days. So, it can be suggested the antidiabetic effect of turkesterone, isolated from Ajugaturkestanikaappears faster than the effect of phytoecdisteroid complex from Ajugaiva. Hence, turkesterone isolated from Ajugaturkestanicahas shown the same anti-diabetic effect as glibenclamide. Also, turkestone appears as an anti-pancreatic property. However, the use of turkesterone in clinical practice for the treatment of diabetes and other pancreatic diseases requires additional research.

\section{CONCLUSION}

Turkesterone separated from A. Turkestanika has a recovering effect on the endosecretion and exosecretion of the pancreas in alloxan-induced diabetic rats. This is manifested in the restoration of the structure of endocrine islets and exocrine acini, as well as in an increase in insulin and Cpeptide levels and a decrease in blood glucose levels in rats with experimental diabetes. Hence, after relevant research, turkesterone can be recommended for the correction of type 1 diabetes in humans.

\section{ACKNOWLEDGEMENTS}

Authors acknowledge the immense help received from the scholars whose articles are cited and included in the references of the manuscript. The authors are also grateful to the authors/editors. Publishers of all those articles and journals from where the literature for this article has been reviewed and discussed.

The authors also would like to thank Republican specialized scientific-practical medical center of Endocrinology and Republican Pathologic anatomic Center of the Ministry of Health of the Republic of Uzbekistan for their consult and support during the study.

Conflict of interest: There is no conflict of interest associated with this article.

Source of funding: There is no external funding agency associated with this article.

\section{REFERENCES}

1. Kharroubi AT, DarwishHM. Diabetes mellitus: The epidemic of the century. World J Diabetes 2015; 6(6): 850-67.

2. Haliloğlu B, Abalı S, Buğrul F, Çelik E, Baş S, Güran T et al. The distribution of different types of diabetes in childhood: A single center experience. J Clin Res Pediatric Endocrinol 2018; 10(2): 125-30. 
3. Syrov VN, Yuldasheva NH, Egamova FR, Ismailova GI, Abdullaeva ND, Xushbaqtova ZA. Evaluation of the hyperglycemic action of phytoecdisteroids. Exp Clin Pharmacol 2012;75(5): 28-31.

4. Mamatkhanov AU, Yakubova MR, Syrov VN. Isolation of turkesterone from the epigeal part of Ajugaturkestanica and its anabolic activity. Chem Nat Compounds 1998; 34(2): 150-154.

5. Gorelick-Feldman J, Maclean D, Ilic N, Poulev A, Lila MA, Cheng Det al.Phytoecdysteroids increase protein synthesis in skeletal muscle cells. J Agricult Food Chem 2008; 56(10): 35323537.

6. Taleb-Senouci D, Ghomari H, Krouf D, Bouderbala S, Prost J, Lacaille-Dubois MA at al. Antioxidant effect of Ajugaiva aqueous extract in streptozotocin-induced diabetic rats. Phytomedicine 2009; 16(6-7): 623-31.

7. WangJJ, Jin H, Zheng SL, Xia P, Cai Y, Ni XJ. Phytoecdysteroids from Ajugaiva act as potential antidiabetic agent against alloxan-induced diabetic male albino rats. Biomed Pharmacother 2017; 96: 480-488.

8. Ochieng CO, Ishola IO, Opiyo SA, Manguro LA, Owuor PO, Wong KC. Phytoecdysteroids from the stem bark of Vitexdoniana and their anti-inflammatory effect. Planta Medica 2013; 79(1): 52-9.

9. Cocquyt K, Cos P, Herdewijn P, Maes L, Van den Steen PE, LaekemanG.AjugaremotaBenth.: From ethnopharmacology to phytomedical perspective in the treatment of malaria. Phytomedicine 2011; 18 (14): 1229-37.

10. Trenin DS, Volodin VV. 20-Hydroxyecdysone as a human lymphocyte and neutrophil modulator: In vitro evaluation. Arch Insect Biochem Physiol 1999; 41 (3): 156-161.
11. El-Hilaly J, Tahraoui A, Israili ZH, Lyoussi B. Hypolipidemic effects of acute and sub-chronic administration of an aqueous extract of Ajugaiva L. whole plant in normal and diabetic rats. J Ethnopharmacol 2006; 105 (3): 441-448.

12. Lenzen S. The mechanisms of alloxan- and streptozotocin-induced diabetes. J Diabetologia 2008; 51 (2): 216-26.

13. Newsholme P, Haber EP, Hirabara SM, Rebelato EL, Rebelato J, Morgan D, at al. Diabetes-associated cell stress and dysfunction: the role of mitochondrial and non-mitochondrial ROS production and activity. J Physiol 2007; 583(1): 19-24.

14. Vina J, Borras C, Gomez-Cabrera MC, Orr WC. Part of the series: From dietary antioxidants to regulators in cellular signalling and gene expression. Role of reactive oxygen species and (phyto)oestrogens in the modulation of adaptive response to stress. Free Radic Bio Med 2006; 40(2): 111-19.

15. Shah AP, Mourad MM, Bramhall SR. Acute pancreatitis: current perspectives on diagnosis and management. J Inflamm Res 2018; 11: 77-85.

16. Mariani A. Chronic asymptomatic pancreatic hyperenzymemia: Is it a benign anomaly or a disease? J Pancreas 2010; 11(2): 9598.

17. Wynne K, Devereaux B, Dornhorst AJ. Diabetes of the exocrine pancreas. J Gastroenterolol Hepatol 2019; 34(2): 346-354.

18. Alvarez C, López MA. Effect of alloxan diabetes on exocrine pancreatic secretion in the anesthetized rabbit. Int J Pancreatol 1989; 5(3): 229-238. 